\title{
Alternative splicing variant of vascular endothelial growth factor-A is a critical prognostic factor in non-small cell lung cancer
}

\author{
MASAHIRO MATSUYAMA ${ }^{1}$, TSUYOSHI CHIJIWA ${ }^{2,8}$, YOSHIMASA INOUE ${ }^{4}$, YOSHIYUKI ABE ${ }^{3}$, \\ MASATAKE NISHI $^{7}$, NORIYUKI MIYAZAKI ${ }^{2}$, DAISUKE FURUKAWA ${ }^{1}$, MASAYA MUKAI $^{4}$, \\ HIROSHI SUEMIZU ${ }^{6}$, YASUTOMO SEKIDO ${ }^{5}$, YOSHITO UEYAMA ${ }^{5}$ and MASATO NAKAMURA ${ }^{2,6}$
}

Departments of ${ }^{1}$ Surgery and ${ }^{2}$ Pathology, Tokai University School of Medicine, Shimokasuya, Isehara, Kanagawa 259-1193;

${ }^{3}$ Tokorozawa PET Diagnostic Imaging Clinic, Higashi-Sumiyoshi, Tokorozawa, Saitama 359-1124;

Departments of ${ }^{4}$ Surgery and ${ }^{5}$ Pathology, Tokai University Hachioji Hospital, Ishikawa, Hachioji, Tokyo, 192-0032;

${ }^{6}$ Central Institute for Experimental Animals, Nogawa, Kawasaki, Kanagawa 216-0003; ${ }^{7}$ Undersea Medical Center, Nagase,

Yokosuka, Kanagawa 239-0826; ${ }^{8}$ National Disaster Medical Center, Midori-Cho, Tachikawa, Tokyo, 190-0014, Japan

Received July 1, 2009; Accepted August 5, 2009

\section{DOI: 10.3892/or_00000582}

\begin{abstract}
Lung cancer is one of the most common malignant diseases in the world, and its prognosis is generally poor. Cancer and metastasis involve numerous biological steps, including angiogenesis in both the primary and metastatic sites. Although various molecules that are involved in both tumor neovascularization (angiogenesis) and invasion have been identified, little is known about how these molecules interact in cancerous microenvironments. We previously reported that the gene expressions of some factors associated with vascularization correlated with the prognosis of nonsmall cell lung cancer (NSCLC). In this study, we performed multivariate analysis of the mRNA levels of 10 selected genes [VEGF-A, VEGF121, VEGF165, VEGF189, S100A4, E-cadherin, Thrombospondin (TSP)-1, TSP-2, matrix metalloproteinase (MMP)-2, and MMP-9] in 130 NSCLC specimens using the real-time quantitative reverse transcription-polymerase chain reaction. Spearman's rank correlation test was used to determine the co-expression patterns. The analysis demonstrated highly significant coexpressions $(\mathrm{P}<0.0001)$ among the VEGF isoforms (VEGF-A, VEGF121, VEGF165, and VEGF189). We also analyzed the correlations among the prognosis, gene expressions, clinical factors (age and gender), and pathological features (histological types, TNM status, stages, lymphatic involvement, and venous involvement) using the Cox proportional hazards
\end{abstract}

Correspondence to: Dr Masato Nakamura, Department of Pathology, Tokai University School of Medicine 143 Shimokasuya, Isehara, Kanagawa 259-1193, Japan

E-mail: mnakamur@is.icc.u-tokai.ac.jp

Key words: VEGF189, non-small cell lung cancer, prognosis, multivariate analysis model. Multivariate analyses showed that only VEGF189 expression was an independent prognostic indicator $(\mathrm{P}=0.0252)$. The alternative splicing variant VEGF189, the cell binding isoform, plays a leading role in the progression of NSCLC.

\section{Introduction}

Lung cancer is one of the most common malignant diseases in the world, and its prognosis is generally poor. Surgical resection is currently the only potentially curative treatment; however, more than $50 \%$ of all such patients who undergo complete resection show recurrence. Cancer growth and metastasis involve numerous biological steps, including tumor cell invasion, motility, extracellular proteolysis, and angiogenesis in both primary and metastatic sites. Although various molecules that are involved in both tumor invasion and neovascularization have been identified, little is known about how these molecules interact in cancerous microenvironments. We previously reported that several gene expressions correlated with the prognosis of non-small cell lung cancer (NSCLC) or adenocarcinoma (1-7).

Vascular endothelial growth factor (VEGF-A) is one of the well-known molecules associated with neovascularization in the cancerous stroma. Molecular cloning has revealed at least six different isoforms (splicing variants of VEGF-A: VEGF121, VEGF145, VEGF165, VEGF183, VEGF189, and VEGF206) which are generated from a single mRNA by alternative splicing, and which have significantly different biochemical features and biological effects (8-13). We have reported that the expression profiles of VEGF-A isoforms are closely associated with the progression of various malignant neoplasms, including non-small cell lung cancer (NSCLC) $(5,14-16)$. In addition, the progression of pulmonary squamous cell carcinoma or pulmonary adenocarcnoma was proven to be closely associated with the expression of VEGF189 mRNA $(2,5)$. 
Table I. Sequences of PCR primers and probes specific for VEGF-A isoforms and TSP-2.

\begin{tabular}{ll}
\hline & \multicolumn{1}{c}{ Sequence $\left(5^{\prime}-3^{\prime}\right)$} \\
\hline VEGF-A-F & CTT GCC TTG CTG CTC TAC CT \\
VEGF-A-R & GAT TCT GCC CTC CTC CTT CTG \\
VEGF-A-probe & CAT GCC AAG TGG TCC C \\
VEGF189-F & GCG CAA GAA ATC CCG GTA TAA GT \\
VEGF189-R & GCT TTC TCC GCT CTG AGC AA \\
VEGF189-probe & CCT GGA GCG TTC CCT G \\
VEGF165-F & ACA ACA AAT GTG AAT GCA GAC CAA A \\
VEGF165-R & GCT TTC TCC GCT CTG AGC AA \\
VEGF165-probe & CCA CAG GGA TTT TCT \\
VEGF121-F & ACA ACA AAT GTG AAT GCA GAC CAA A \\
VEGF121-R & CTG AGG GAG GCT CCT TCC T \\
VEGF121-probe & CAA GAA AAA TGT GAC AAG CCG \\
TSP-2-F & GCT GGT TCA GAC AGC CAA CTC \\
TSP-2-R & TAA CCA AAG ACG AAG CCA GCA T \\
TSP-2-probe & TGC CAC TGA AGT CCA CAG ACC CAA ACT \\
\hline
\end{tabular}

VEGF, vascular endothelial growth factor; TSP, thrombospondin; F, forward; R, reverse.

Thrombospondin (TSP) is a family of glycoproteins with at least five subtypes encoded by independent genes, in which TSP-1 and TSP-2 contain three properdin-like type-1 repeats, unlike other TSPs (17-19). Only TSP-1 and TSP-2 function as endogenous negative regulators of angiogenesis in tumorigenesis, because their anti-angiogenic activity has been mapped to the type- 1 repeats $(4,20,21)$. Angiogenesis is partially regulated by the balance between the angiogenic inducer VEGF and the angiogenic inhibitor TSP $(22,23)$. However, TSP mediation of the angioinhibitory effect is facilitated not only by VEGF but also by some matrix proteases (24-27).

Extracellular proteolysis for degradation of the extracellular matrix is very important for angiogenesis and cancerous cell invasion. This allows endothelial and tumor cells to migrate through the tissue stroma and subsequently to enter and spread via the blood and/or lymphatic systems. The matrix metalloproteinases (MMPs), including MMP-2 and MMP-9 (gelatinase-A and $-\mathrm{B}$, respectively), are amongst the most extensively studied proteases in this respect.

E-cadherin is the main cell-to-cell adhesion molecule that participates in homophilic, calcium-dependent interactions to form the epithelial adherence junction $(28,29)$. Thus, E-cadherin is assumed to act as the main invasionsuppressor molecule $(30,31)$. The S100 family of calciumbinding proteins is associated with a variety of physiological functions, such as cellular proliferation, adhesion, and motility (32). In pulmonary adenocarinoma cases, those expressing combined lower E-cadherin and higher S-100A4, a small member of the $\mathrm{S} 100$ family which is associated with an increased metastatic capacity of cancer cells, levels showed a significantly poorer prognosis, although each of E-cadherin and S100A4 gene expressions did not independently contribute to the prognosis $(3,33,34)$.

The aim of our study was to identify which genes are co-expressed in tumors in which angiogenesis and/or lymphangiogenesis are prominent. We performed multivariate analysis of the mRNA levels of the above-described 10 genes
(VEGF-A, VEGF121, VEGF165, VEGF189, S100A4, E-cadherin, TSP-1, TSP-2, MMP-2, and MMP-9) in 130 NSCLC specimens using the real-time quantitative reverse transcription-polymerase chain reaction (RT-PCR). We also evaluated the clinical prognosis based on long-term observation periods of 5 to 15 years.

\section{Materials and methods}

Patients. One hundred and thirty NSCLC specimens were obtained from surgical specimens with the patients' informed consent from October 1985 to November 1995. All cases underwent complete resection (lobectomy or pneumonectomy and dissection of mediastinal lymph nodes) of NSCLC. Tissues were immediately frozen and stored at $-80^{\circ} \mathrm{C}$ until analysis. Surgical specimens were also processed for routine histopathological analysis. The pathological features of the samples were classified according to the WHO histological criteria (35).

The patients consisted of 82 men and 48 women, with a mean age of $62.60 \pm 9.16$ years. The pathological classifications were 98 adenocarcinomas, 27 squamous cell carcinomas, 2 adenosquamous carcinomas, and 3 large cell carcinomas. The tumor status was $\mathrm{T} 1$ in 48 patients, $\mathrm{T} 2$ in 63 , T3 in 15, and T4 in 4. The lymph node status was N0 in 76 patients, $\mathrm{N} 1$ in $15, \mathrm{~N} 2$ in 38 , and N3 in 1 . The pathological stages were as follows: stage I, 69 patients; stage II, 18; stage III, 43; stage IV, 0. Lymphatic involvement was noted in 66 cases $(50.8 \%)$, with venous involvement in 68 (52.3\%).

RNA extraction and preparation of cDNA. Total cellular RNA was prepared from the frozen specimens by standard acid guanidine isothiocyanate-phenol-chloroform extraction procedures. After the heat-denaturation of total RNA specimens $(1 \mu \mathrm{g})$, reverse transcription was performed $[10 \mathrm{mM}$ DTT (Invitrogen Corp., Carlsbad, CA, USA), 0.2 mM dNTPs (Toyobo Co., Osaka, Japan), 100 pmol of Primer, Random 


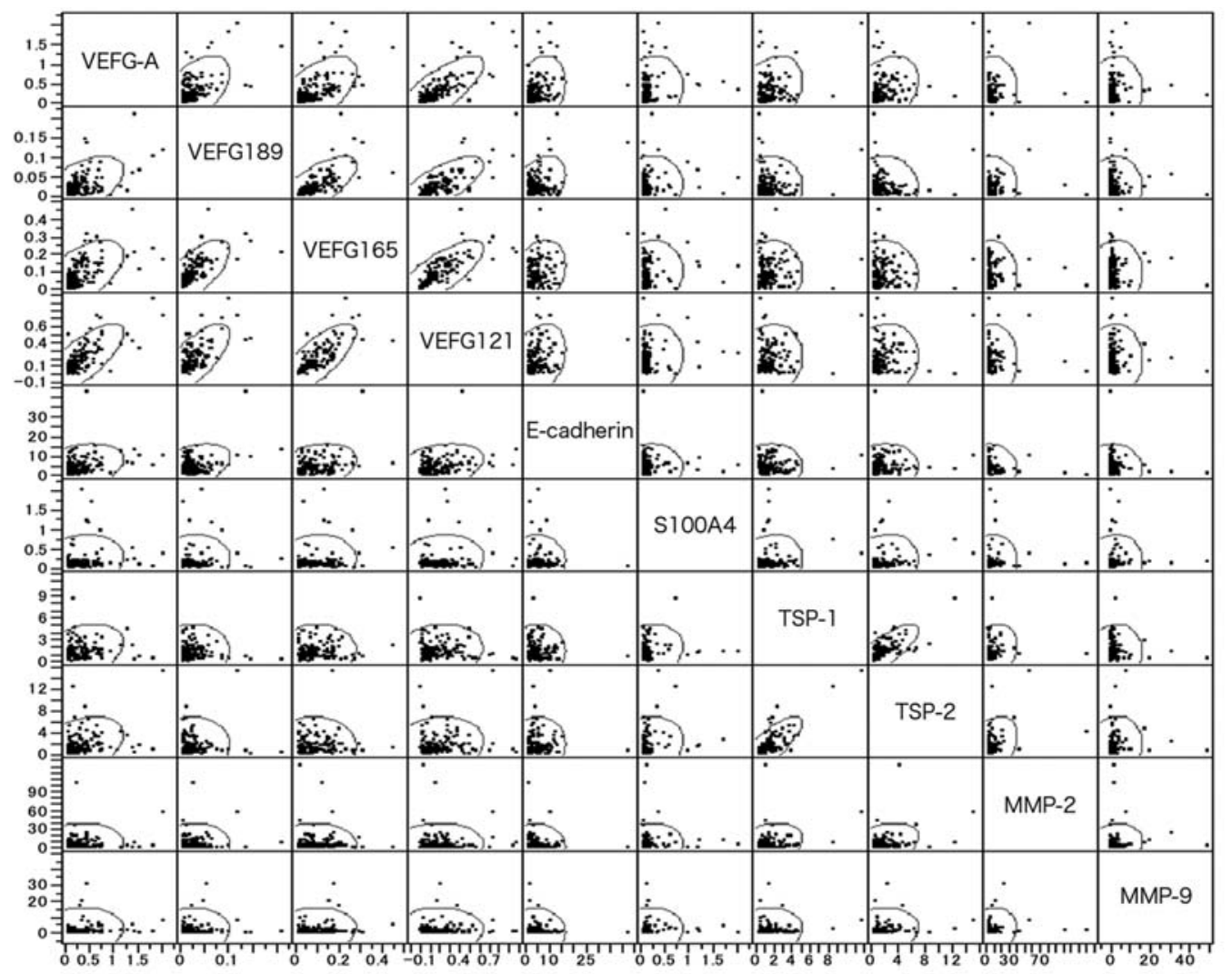

\section{Co-expression patterns of ten selected genes in non-small cell lung cancer}

Figure 1. Co-expression patterns of ten selected genes in non-small cell lung cancer. VEGF, vascular endothelial growth factor; TSP, thrombospondin; MMP, matrix metalloproteinase.

PD (N6) (Roche Diagonostics Co., Indianapolis, IN, USA), and 200 Units of Superscript ${ }^{\mathrm{TM}}$ II RNase H-Reverse Transcriptase (Invitrogen) at $\left.42^{\circ} \mathrm{C}, 60 \mathrm{~min}\right](2,7)$.

Real-time quantitative RT-PCR. Real-time quantitative RT-PCR for VEGF-A, VEGF121, VEGF165, VEGF189, S100A4, E-cadherin, TSP-1, TSP-2, MMP-2, MMP-9, and B-actin mRNA was performed according to the manufacturer's recommendations. The primers used for TSP-2 and VEGF-A are shown in Table I. The primers for TSP-1 (Hs00170236), S100A4 (Hs00243201), E-cadherin (Hs00170423), MMP-2 (Hs00234422), and MMP-9 (Hs00234579) were purchased from TaqMan ${ }^{\circledR}$ Gene Expression Assays (PE Applied Biosystems, Foster City, CA, USA). We used TaqMan ${ }^{\circledR}$ Universal PCR Master Mix (PE Applied Biosystems) for the real-time PCR. For the internal controls, $\beta$-actin-probe-primer mixture for $\beta$-actin mRNA was used (human ACTB, 4310881E, PE Applied Biosystems). Real-time PCR assays were duplicated using an ABI PRISM 7000 Sequence Detection System (PE Applied Biosystems) with the following protocol: after initial denaturation: $2 \mathrm{~min}$ at $50^{\circ} \mathrm{C}$ and $10 \mathrm{~min}$ at $95^{\circ} \mathrm{C}$, amplification: 50 cycles of $15 \mathrm{sec}$ at $95^{\circ} \mathrm{C}$ and $60 \mathrm{sec}$ at $60^{\circ} \mathrm{C}$. We determined the threshold cycle $(\mathrm{Ct})$, which was defined as the PCR cycle number at which point the fluorescence intensity exceeded the threshold from the $\mathrm{Ct}$ of the sample and the RNA standard curve. Then, the relationship between the $\mathrm{Ct}$ and initial standard copy number was expressed as a logarithmic formula. The obtained copy of each gene was then standardized with the $\beta$-actin mRNA quantity as the endogenous control using the following equation: Result $=\log$ (RNA copy number of each gene in sample/ß-actin RNA copy number in sample) $\mathrm{x}\left(6.1 \times 10^{9}\right)$.

Statistical analysis. Data are shown as the mean \pm standard deviation (SD). Spearman's rank correlation test was used to compare the co-expression patterns. On multivariate analyses, the Cox proportional hazards model was used. These analyses were performed using the JMP version 6 software (SAS Institute Inc., Cary, NC, USA). P-values <0.05 were considered significant.

\section{Results}

Gene expressions of NSCLC. All NSCLC cases showed significant gene expressions by real-time PCR. The gene expression level of VEGF-A was $0.3314 \pm 0.3389$, and those of isoforms were as follows: VEGF189, 0.02811 \pm 0.02904 ; VEGF165, 0.09372 \pm 0.07272 ; VEGF121, 0.1850 \pm 0.1769 . The gene expression level of E-cadherin was 5.356 \pm 4.554 , S100A 4 was $0.1935 \pm 0.2770$, TSP-1 was $1.578 \pm 1.425$, TSP-2 was $1.884 \pm 2.077$, MMP-2 was $8.549 \pm 15.250$, and MMP-9 was $2.327 \pm 5.451$.

Gene co-expression patterns in NSCLC. Fig. 1 shows the gene co-expression pattern of 10 selected cancer-related molecules. Spearman's rank correlation test disclosed many 
Table II. Spearman's correlation matrix to assess gene co-expressions (with rho and P-values) in non-small cell lung cancer.

\begin{tabular}{|c|c|c|c|c|c|c|c|c|c|c|}
\hline & VEGF-A & VEGF189 & VEGF165 & VEGF121 & E-cadherin & S100A4 & TSP-1 & TSP-2 & MMP-2 & MMP-9 \\
\hline $\begin{array}{l}\text { VEGF-A } \\
\text { rho } \\
\text { P-value }\end{array}$ & 1 & $\begin{array}{c}0.423 \\
<\mathbf{0 . 0 0 0 1}\end{array}$ & $\begin{array}{c}0.609 \\
<\mathbf{0 . 0 0 0 1}\end{array}$ & $\begin{array}{c}0.706 \\
<\mathbf{0 . 0 0 0 1}\end{array}$ & $\begin{array}{l}0.270 \\
\mathbf{0 . 0 0 1}\end{array}$ & $\begin{array}{l}0.188 \\
\mathbf{0 . 0 2 8}\end{array}$ & $\begin{array}{l}0.177 \\
\mathbf{0 . 0 3 7}\end{array}$ & $\begin{array}{r}0.317 \\
<\mathbf{0 . 0 0 1}\end{array}$ & $\begin{array}{r}-0.031 \\
0.714\end{array}$ & $\begin{array}{l}0.220 \\
\mathbf{0 . 0 0 9}\end{array}$ \\
\hline $\begin{array}{l}\text { VEGF189 } \\
\text { rho } \\
\text { P-value }\end{array}$ & $\begin{array}{c}0.423 \\
<\mathbf{0 . 0 0 0 1}\end{array}$ & 1 & $\begin{array}{c}0.798 \\
<\mathbf{0 . 0 0 0 1}\end{array}$ & $\begin{array}{c}0.676 \\
<\mathbf{0 . 0 0 0 1}\end{array}$ & $\begin{array}{l}0.141 \\
0.101\end{array}$ & $\begin{array}{r}-0.118 \\
0.169\end{array}$ & $\begin{array}{r}-0.158 \\
0.064\end{array}$ & $\begin{array}{r}-0.173 \\
\mathbf{0 . 0 4 2}\end{array}$ & $\begin{array}{r}-0.025 \\
0.766\end{array}$ & $\begin{array}{r}-0.020 \\
0.812\end{array}$ \\
\hline $\begin{array}{l}\text { VEGF165 } \\
\text { rho } \\
\text { P-value }\end{array}$ & $\begin{array}{c}0.609 \\
<\mathbf{0 . 0 0 0 1}\end{array}$ & $\begin{array}{c}0.798 \\
<\mathbf{0 . 0 0 0 1}\end{array}$ & 1 & $\begin{array}{c}0.859 \\
<\mathbf{0 . 0 0 0 1}\end{array}$ & $\begin{array}{l}0.164 \\
0.056\end{array}$ & $\begin{array}{r}-0.109 \\
0.205\end{array}$ & $\begin{array}{l}0.017 \\
0.843\end{array}$ & $\begin{array}{l}0.010 \\
0.910\end{array}$ & $\begin{array}{r}-0.008 \\
0.921\end{array}$ & $\begin{array}{l}0.115 \\
0.176\end{array}$ \\
\hline $\begin{array}{l}\text { VEGF121 } \\
\text { rho } \\
\text { P-value }\end{array}$ & $\begin{array}{c}0.706 \\
<\mathbf{0 . 0 0 0 1}\end{array}$ & $\begin{array}{c}0.676 \\
<\mathbf{0 . 0 0 0 1}\end{array}$ & $\begin{array}{c}0.859 \\
<\mathbf{0 . 0 0 0 1}\end{array}$ & 1 & $\begin{array}{r}0.282 \\
<\mathbf{0 . 0 0 1}\end{array}$ & $\begin{array}{r}-0.047 \\
0.586\end{array}$ & $\begin{array}{l}0.033 \\
0.703\end{array}$ & $\begin{array}{l}0.103 \\
0.226\end{array}$ & $\begin{array}{l}0.040 \\
0.638\end{array}$ & $\begin{array}{l}0.150 \\
0.078\end{array}$ \\
\hline $\begin{array}{l}\text { E-cadherin } \\
\text { rho } \\
\text { P-value }\end{array}$ & $\begin{array}{l}0.270 \\
\mathbf{0 . 0 0 1}\end{array}$ & $\begin{array}{l}0.141 \\
0.101\end{array}$ & $\begin{array}{l}0.164 \\
0.056\end{array}$ & $\begin{array}{r}0.282 \\
<\mathbf{0 . 0 0 1}\end{array}$ & 1 & $\begin{array}{r}-0.010 \\
0.910\end{array}$ & $\begin{array}{r}-0.068 \\
0.435\end{array}$ & $\begin{array}{l}0.062 \\
0.481\end{array}$ & $\begin{array}{r}-0.162 \\
0.060\end{array}$ & $\begin{array}{r}-0.247 \\
\mathbf{0 . 0 0 4}\end{array}$ \\
\hline $\begin{array}{l}\text { S100A4 } \\
\text { rho } \\
\text { P-value }\end{array}$ & $\begin{array}{l}0.188 \\
\mathbf{0 . 0 2 8}\end{array}$ & $\begin{array}{r}-0.118 \\
0.169\end{array}$ & $\begin{array}{r}-0.109 \\
0.205\end{array}$ & $\begin{array}{r}-0.047 \\
0.586\end{array}$ & $\begin{array}{r}-0.010 \\
0.910\end{array}$ & 1 & $\begin{array}{l}0.160 \\
0.065\end{array}$ & $\begin{array}{l}0.121 \\
0.162\end{array}$ & $\begin{array}{l}0.142 \\
0.100\end{array}$ & $\begin{array}{c}0.368 \\
<\mathbf{0 . 0 0 0 1}\end{array}$ \\
\hline $\begin{array}{l}\text { TSP-1 } \\
\text { rho } \\
\text { P-value }\end{array}$ & $\begin{array}{l}0.177 \\
\mathbf{0 . 0 3 7}\end{array}$ & $\begin{array}{r}-0.158 \\
0.064\end{array}$ & $\begin{array}{l}0.017 \\
0.843\end{array}$ & $\begin{array}{l}0.033 \\
0.703\end{array}$ & $\begin{array}{r}-0.068 \\
0.435\end{array}$ & $\begin{array}{l}0.160 \\
0.065\end{array}$ & 1 & $\begin{array}{c}0.668 \\
<\mathbf{0 . 0 0 0 1}\end{array}$ & $\begin{array}{l}0.211 \\
0.013\end{array}$ & $\begin{array}{l}0.147 \\
0.085\end{array}$ \\
\hline $\begin{array}{l}\text { TSP-2 } \\
\text { rho } \\
\text { P-value }\end{array}$ & $\begin{array}{r}0.317 \\
<\mathbf{0 . 0 0 1}\end{array}$ & $\begin{array}{r}-0.173 \\
\mathbf{0 . 0 4 2}\end{array}$ & $\begin{array}{l}0.010 \\
0.910\end{array}$ & $\begin{array}{l}0.103 \\
0.226\end{array}$ & $\begin{array}{l}0.062 \\
0.481\end{array}$ & $\begin{array}{l}0.121 \\
0.162\end{array}$ & $\begin{array}{c}0.668 \\
<\mathbf{0 . 0 0 0 1}\end{array}$ & 1 & $\begin{array}{c}0.350 \\
<\mathbf{0 . 0 0 0 1}\end{array}$ & $\begin{array}{r}0.312 \\
<\mathbf{0 . 0 0 1}\end{array}$ \\
\hline $\begin{array}{l}\text { MMP-2 } \\
\text { rho } \\
\text { P-value }\end{array}$ & $\begin{array}{r}-0.031 \\
0.714\end{array}$ & $\begin{array}{r}-0.025 \\
0.766\end{array}$ & $\begin{array}{c}-0.008 \\
0.921\end{array}$ & $\begin{array}{l}0.040 \\
0.638\end{array}$ & $\begin{array}{r}-0.162 \\
0.060\end{array}$ & $\begin{array}{l}0.142 \\
0.100\end{array}$ & $\begin{array}{l}0.211 \\
0.013\end{array}$ & $\begin{array}{c}0.350 \\
<\mathbf{0 . 0 0 0 1}\end{array}$ & 1 & $\begin{array}{l}0.180 \\
\mathbf{0 . 0 3 3}\end{array}$ \\
\hline $\begin{array}{l}\text { MMP-9 } \\
\text { rho } \\
\text { P-value }\end{array}$ & $\begin{array}{l}0.220 \\
\mathbf{0 . 0 0 9}\end{array}$ & $\begin{array}{r}-0.020 \\
0.812\end{array}$ & $\begin{array}{l}0.115 \\
0.176\end{array}$ & $\begin{array}{l}0.150 \\
0.078\end{array}$ & $\begin{array}{r}-0.247 \\
\mathbf{0 . 0 0 4}\end{array}$ & $\begin{array}{c}0.368 \\
<\mathbf{0 . 0 0 0 1}\end{array}$ & $\begin{array}{l}0.147 \\
0.085\end{array}$ & $\begin{array}{r}0.312 \\
<\mathbf{0 . 0 0 1}\end{array}$ & $\begin{array}{l}0.180 \\
\mathbf{0 . 0 3 3}\end{array}$ & 1 \\
\hline
\end{tabular}

VEGF, vascular endothelial growth factor; TSP, thrombospondin; MMP, matrix metalloproteinase. Values in bold type indicate significant differences.

significant relations (Table II). The analysis demonstrated highly significant co-expressions $(\mathrm{P}<0.0001)$ among the VEGF isoforms (VEGF-A, VEGF121, VEGF165, and VEGF189). Moreover, the following significant co-expression patterns were also observed: VEGF-A and E-cadherin $(\mathrm{P}=0.001)$, VEGF-A and S100A4 ( $\mathrm{P}=0.028)$, VEGF-A and TSP-1 $(\mathrm{P}=0.037)$, VEGF-A and TSP-2 $(\mathrm{P}<0.001), \mathrm{VEGF}-\mathrm{A}$ and MMP-9 $(\mathrm{P}=0.009)$, VEGF121 and E-cadherin $(\mathrm{P}<0.001)$, VEGF189 and TSP-2 (P=0.042), TSP-1 and TSP-2 $(\mathrm{P}<0.0001)$, TSP-1 and MMP-2 ( $\mathrm{P}=0.013)$, TSP-2 and MMP-2 $(\mathrm{P}<0.0001)$, MMP-9 and E-cadherin $(\mathrm{P}=0.004)$, MMP-9 and S100A4 $(\mathrm{P}<0.0001)$, MMP-9 and TSP-2 $(\mathrm{P}<0.001)$, and MMP-9 and MMP-2 ( $\mathrm{P}=0.033)$.

Gene expression and clinicopathological features. We also analyzed correlations among the prognosis, gene expressions, clinical factors (age and gender), and pathological features (histological types, TNM status, stages, lymphatic involvement, and venous involvement) using the Cox proportional hazards model. Multivariate analyses showed that only VEGF189 expression was an independent prognostic indicator $(\mathrm{P}=0.025$, Table III).

\section{Discussion}

In this study, we identified many co-expression patterns centering on VEGF isoforms. There were strong interactions between VEGF-A and its isofoms (VEGF121, VEGF165, and VEGF189). Table I shows two clusters of gene co-expression: one is the aforementioned group centering on VEGF isoforms, and the other is a group consisting of TSP-1, -2, MMP-2, and -9. However, few significant relationships were observed among VEGF-A splice variants and MMPs. Only between MMP-9 and VEGF-A there was a significant 
Table III. Multivariate analyses using the Cox proportional hazards model.

\begin{tabular}{llr}
\hline Variable & \multicolumn{1}{c}{ Strata } & P-value \\
\hline Age & 62.60 \pm 9.16 & 0.562 \\
Gender & Male, Female & 0.355 \\
Histological types & Ad, Sq, AdSq, La & 0.109 \\
T status & T1, T2, T3, T4 & 0.433 \\
N status & N0, N1, N2, N3 & 0.535 \\
Stages & $\mathrm{I}, \mathrm{II}, \mathrm{III}$ & 0.198 \\
Lymphatic involvement & ly(+), ly(-) & 0.068 \\
Venous involvement & $\mathrm{v}(+), \mathrm{v}(-)$ & 0.781 \\
VEGF-A & $0.3314 \pm 0.3389$ & 0.376 \\
VEGF189 & $0.02811 \pm 0.02904$ & $\mathbf{0 . 0 2 5}$ \\
VEGF165 & $0.09372 \pm 0.07272$ & 0.700 \\
VEGF121 & $0.1850 \pm 0.1769$ & 0.149 \\
E-cadherin & $5.356 \pm 4.554$ & 0.135 \\
S100A4 & $0.1935 \pm 0.2770$ & 0.311 \\
TSP-1 & $1.578 \pm 1.425$ & 0.472 \\
TSP-2 & $1.884 \pm 2.077$ & 0.081 \\
MMP-2 & $8.549 \pm 15.250$ & 0.237 \\
MMP-9 & $2.327 \pm 5.451$ & 0.416 \\
\hline
\end{tabular}

Ad, adenocarcinoma; Sq, squamous cell carcinoma; AdSq, adenosquamous carcinoma; La, large cell carcinoma; VEGF, vascular endothelial growth factor; TSP, thrombospondin; MMP, matrix metalloproteinase. ${ }^{*} \mathrm{P}<0.05$.

co-expression pattern. Regarding co-expressions among VEGF-A isoforms, correlations between VEGF121 and VEGF165 in NSCLC and among VEGF-C, the lymphangiogenic factor, as well as VEGF-A isoforms in cervical cancer were reported $(36,37)$. There are many reports that TSPs interact with MMPs but not VEGFs in various malignant neoplasms $(1,23,38-40)$. In the Cox proportional hazards model, the gene expression of VEGF189 was proven to be the only independent prognostic indicator of NSCLC.

Some studies reported that VEGF-A gene expression was related to the clinical prognosis in $\operatorname{NSCLC}(5,36,41)$. Previously, we demonstrated that the expression of VEGF189 was associated with a poor prognosis in squamous cell carcinoma using the RT-PCR assay (5). In another study using real-time PCR, we clearly demonstrated that VEGF189 overexpression was quantitatively related to vascularization, the postoperative relapse time, and prognosis based on long-term observation periods in pulmonary adenocarcinoma (2). Yuan et al reported that VEGF189 expression showed a stronger correlation with tumor angiogenesis and survival than other VEGF-A isoforms in NSCLC by RT-PCR (36). We reported that patients with pulmonary adenocarcinoma overexpressing VEGF189 showed a significantly higher incidence of intrapulmonary, bone, and hepatic metastasis (2). We also reported that VEGF189 was seen in the cytoplasm of tumor cells of pulmonary adenocarcinoma overexpressing the VEGF189 gene by immunohistochemistry (2). The results suggest that the cellular binding isoform VEGF189 works in the micro- environment of the primary cancer lesion. Many reports employing immunohistochemical analysis showed that VEGF-A expression was related to angiogenesis in NSCLC, and that not only VEGF-A expression but also other factors affected the clinical prognosis (42-46).

The larger isoforms VEGF189 and VEGF206 are cellassociated and show heparin-binding activity, while the smaller isoforms VEGF121 and VEGF165 are secretory proteins (8). VEGF189 is more strongly associated with the cell membrane than VEGF121 or VEGF165. The lung cancer cell lines that specifically suppressed VEGF189 expression showed decreased growth properties in vivo (6). The in vivo tumor growth of VEGF189 transfectants was faster than that of VEGF121 transfectants (47). The protein levels of VEGF-A were not increased in the supernatant of VEGF189 transfectant culture. The in vivo growth enhancement of VEGF189 transfectants was due to the unique features of VEGF189 molecules in the cancer microenvironment.

TSP-2 was a prognostic indicator following VEGF189 in gene expressions, however, non-significant $(\mathrm{P}=0.081)$. Angiogenesis is partially regulated by the balance between the angiogenic inducer VEGF and angiogenic inhibitor TSP-2 (22). The mediation by TSP-2 of the angioinhibitory effect might be induced not only by VEGF but also by some matrix proteases $(24,25)$. MMPs play active roles during matrix remodeling and other tissue regeneration processes, including the modulation of angiogenesis.

In multivariate analysis of clinicopathological features and the survival rate, VEGF expression in esophageal squamous cell carcinoma and VEGF189 expression in NSCLC were reported to be independent prognostic factors $(36,48)$. However, these studies did not analyze gene expressions except for VEGF isoforms. Multivariate analysis of various kinds of gene expression measured quantitatively by real-time RT-PCR and prognosis have yet to be published. In this study, we identified many associations between VEGF isoforms and other cancer molecules. It is concluded that the alternative splicing variant VEGF189, the cell binding isoform, plays a leading role in the progression of NSCLC.

\section{Acknowledgements}

We are grateful to Dr Johbu Itoh and Mr. Yuichi Tada (Department of Pathology, Tokai University) for their technical assistance and helpful discussion.

\section{References}

1. Oshika Y, Masuda K, Tokunaga T, Hatanaka H, Kamiya T, Abe Y, Ozeki Y, Kijima H, Yamazaki H, Tamaoki N, Ueyama Y and Nakamura M: Thrombospondin 2 gene expression is correlated with decreased vascularity in non-small cell lung cancer. Clin Cancer Res 4: 1785-1788, 1998.

2. Nishi M, Abe Y, Tomii Y, Tsukamoto H, Kijima H, Yamazaki H, Ohnishi Y, Iwasaki M, Inoue H, Ueyama Y and Nakamura M: Cell binding isoforms of vascular endothelial growth factorA (VEGF189) contribute to blood flow-distant metastasis of pulmonary adenocarcinoma. Int J Oncol 26: 1517-1524, 2005.

3. Miyazaki N, Abe Y, Oida Y, Suemizu H, Nishi M, Yamazaki H, Iwasaki M, Inoue H, Ueyama Y and Nakamura M: Poor outcome of patients with pulmonary adenocarcinoma showing decreased E-cadherin combined with increased S100A4 expression. Int J Oncol 28: 1369-1374, 2006. 
4. Chijiwa T, Abe $\mathrm{Y}$, Inoue $\mathrm{Y}$, Matsumoto $\mathrm{H}$, Kawai $\mathrm{K}$ Matsuyama M, Miyazaki N, Inoue H, Mukai M, Ueyama Y and Nakamura M: Cancerous, but not stromal, thrombospondin-2 contribute prognosis in pulmonary adenocarcinoma. Oncol Rep 22: 279-283, 2009.

5. Oshika Y, Nakamura M, Tokunaga T, Ozeki Y, Fukushima Y, Hatanaka H, Abe Y, Yamazaki H, Kijima H, Tamaoki N and Ueyama Y: Expression of cell-associated isoform of vascular endothelial growth factor 189 and its prognostic relevance in non-small cell lung cancer. Int J Oncol 12: $541-544,1998$.

6. Oshika Y, Nakamura M, Tokunaga T, Ohnishi Y, Abe Y, Tsuchida T, Tomii Y, Kijima H, Yamazaki H, Ozeki Y, Tamaoki N and Ueyama Y: Ribozyme approach to down-regulate vascular endothelial growth factor (VEGF) 189 expression in non-small cell lung cancer (NSCLC). Eur J Cancer 36: 2390-2396, 2000.

7. Abe Y, Ohnishi Y, Yoshimura M, Ota E, Ozeki Y, Oshika Y, Tokunaga T, Yamazaki H, Ueyema Y, Ogata T, Tamaoki N and Nakamura M: P-glycoprotein-mediated acquired multidrug resistance of human lung cancer cells in vivo. $\mathrm{Br} \mathrm{J}$ Cancer 74 : 1929-1934, 1996.

8. Park JE, Keller GA and Ferrara N: The vascular endothelial growth factor (VEGF) isoforms: differential deposition into the subepithelial extracellular matrix and bioactivity of extracellular matrix-bound VEGF. Mol Biol Cell 4: 1317-1326, 1993.

9. Ferrara N, Houck KA, Jakeman LB, Winer J and Leung DW: The vascular endothelial growth factor family of polypeptides. J Cell Biochem 47: 211-218, 1991.

10. Houck KA, Ferrara N, Winer J, Cachianes G, Li B and Leung DW: The vascular endothelial growth factor family: identification of a fourth molecular species and characterization of alternative splicing of RNA. Mol Endocrinol 5: 1806-1814, 1991.

11. Veikkola T and Alitalo K: VEGFs, receptors and angiogenesis. Semin Cancer Biol 9: 211-220, 1999.

12. Yancopoulos GD, Davis S, Gale NW, Rudge JS, Wiegand SJ and Holash J: Vascular-specific growth factors and blood vessel formation. Nature 407: 242-248, 2000.

13. Poltorak Z, Cohen T, Sivan R, Kandelis Y, Spira G, Vlodavsky I, Keshet E and Neufeld G: VEGF145, a secreted vascular endothelial growth factor isoform that binds to extracellular matrix. J Biol Chem 272: 7151-7158, 1997

14. Tokunaga T, Oshika Y, Abe Y, Ozeki Y, Sadahiro S, Kijima H, Tsuchida T, Yamazaki H, Ueyama Y, Tamaoki $\mathrm{N}$ and Nakamura M: Vascular endothelial growth factor (VEGF) mRNA isoform expression pattern is correlated with liver metastasis and poor prognosis in colon cancer. $\mathrm{Br} \mathrm{J}$ Cancer 77: 998-1002, 1998

15. Tomisawa M, Tokunaga T, Oshika Y, Tsuchida T, Fukushima Y, Sato H, Kijima H, Yamazaki H, Ueyama Y, Tamaoki N and Nakamura M: Expression pattern of vascular endothelial growth factor isoform is closely correlated with tumour stage and vascularisation in renal cell carcinoma. Eur J Cancer 35: $133-137,1999$

16. Lee YH, Tokunaga T, Oshika Y, Suto R, Yanagisawa K, Tomisawa M, Fukuda H, Nakano H, Abe S, Tateishi A, Kijima $H$, Yamazaki H, Tamaoki N, Ueyama Y and Nakamura M: Cellretained isoforms of vascular endothelial growth factor (VEGF) are correlated with poor prognosis in osteosarcoma. Eur J Cancer 35: 1089-1093, 1999

17. Good DJ, Polverini PJ, Rastinejad F, Le Beau MM, Lemons RS, Frazier WA and Bouck NP: A tumor suppressor-dependent inhibitor of angiogenesis is immunologically and functionally indistinguishable from a fragment of thrombospondin. Proc Natl Acad Sci USA 87: 6624-6628, 1990

18. Streit M, Riccardi L, Velasco P, Brown LF, Hawighorst T, Bornstein P and Detmar M: Thrombospondin-2: a potent endogenous inhibitor of tumor growth and angiogenesis. Proc Natl Acad Sci USA 96: 14888-14893, 1999.

19. Kyriakides TR, Zhu YH, Yang Z and Bornstein P: The distribution of the matricellular protein thrombospondin 2 in tissues of embryonic and adult mice. J Histochem Cytochem 46: 1007-1015, 1998.

20. Lawler J: The functions of thrombospondin-1 and-2. Curr Opin Cell Biol 12: 634-640, 2000.

21. Tolsma SS, Volpert OV, Good DJ, Frazier WA, Polverini PJ and Bouck N: Peptides derived from two separate domains of the matrix protein thrombospondin- 1 have anti-angiogenic activity. J Cell Biol 122: 497-511, 1993.
22. Kim MS, Kim YK, Cho KH and Chung JH: Infrared exposure induces an angiogenic switch in human skin that is partially mediated by heat. Br J Dermatol 155: 1131-1138, 2006.

23. Tokunaga T, Nakamura M, Oshika Y, Abe Y, Ozeki Y, Fukushima Y, Hatanaka H, Sadahiro S, Kijima H, Tsuchida T, Yamazaki H, Tamaoki N and Ueyama Y: Thrombospondin 2 expression is correlated with inhibition of angiogenesis and metastasis of colon cancer. Br J Cancer 79: 354-359, 1999.

24. Werb Z, Vu TH, Rinkenberger JL and Coussens LM: Matrixdegrading proteases and angiogenesis during development and tumor formation. APMIS 107: 11-18, 1999.

25. Kyriakides TR, Zhu YH, Yang Z, Huynh G and Bornstein P. Altered extracellular matrix remodeling and angiogenesis in sponge granulomas of thrombospondin 2-null mice. Am J Pathol 159: 1255-1262, 2001

26. Oida Y, Yamazaki H, Tobita K, Mukai M, Ohtani Y, Miyazaki N, Abe Y, Imaizumi T, Makuuchi H, Ueyama Y and Nakamura M: Increased S100A4 expression combined with decreased Ecadherin expression predicts a poor outcome of patients with pancreatic cancer. Oncol Rep 16: 457-463, 2006.

27. Kamochi J, Tokunaga T, Tomii Y, Abe Y, Hatanaka H, Kijima H, Yamazaki H, Watanabe N, Matsuzaki S, Ueyama Y and Nakamura M: Overexpression of the thrombospondin 2 (TSP2) gene modulated by the matrix metalloproteinase family expression and production in human colon carcinoma cell line. Oncol Rep 10: 881-884, 2003

28. Takeichi M: Cadherin cell adhesion receptors as a morphogenetic regulator. Science 251: 1451-1455, 1991

29. Wheelock MJ and Jensen PJ: Regulation of keratinocyte intercellular junction organization and epidermal morphogenesis by E-cadherin. J Cell Biol 117: 415-425, 1992.

30. Frixen UH, Behrens J, Sachs M, Eberle G, Voss B, Warda A, Lochner D and Birchmeier W: E-cadherin-mediated cell-cell adhesion prevents invasiveness of human carcinoma cells. J Cell Biol 113: 173-185, 1991

31. Behrens J, Mareel MM, Van Roy FM and Birchmeier W: Dissecting tumor cell invasion: epithelial cells acquire invasive properties after the loss of uvomorulin-mediated cell-cell adhesion. J Cell Biol 108: 2435-2447, 1989.

32. Schafer BW and Heizmann CW: The S100 family of EF-hand calcium-binding proteins: functions and pathology. Trends Biochem Sci 21: 134-140, 1996.

33. Takenaga K, Nakamura Y and Sakiyama S: Expression of antisense RNA to S100A4 gene encoding an S100-related calcium-binding protein suppresses metastatic potential of high-metastatic Lewis lung carcinoma cells. Oncogene 14: 331-337, 1997.

34. Maelandsmo GM, Hovig E, Skrede M, Engebraaten O, Florenes VA, Myklebost O, Grigorian M, Lukanidin E, Scanlon KJ and Fodstad O: Reversal of the in vivo metastatic phenotype of human tumor cells by an anti-CAPL (mts1) ribozyme. Cancer Res 56: 5490-5498, 1996.

35. The World Health Organization histological typing of lung tumours. Second edition. Am J Clin Pathol 77: 123-136, 1982.

36. Yuan A, Yu CJ, Kuo SH, Chen WJ, Lin FY, Luh KT, Yang PC and Lee YC: Vascular endothelial growth factor 189 mRNA isoform expression specifically correlates with tumor angiogenesis, patient survival, and postoperative relapse in nonsmall-cell lung cancer. J Clin Oncol 19: 432-441, 2001.

37. Van Trappen PO, Ryan A, Carroll M, Lecoeur C, Goff L, Gyselman VG, Young BD, Lowe DG, Pepper MS, Shepherd JH and Jacobs IJ: A model for co-expression pattern analysis of genes implicated in angiogenesis and tumour cell invasion in cervical cancer. Br J Cancer 87: 537-544, 2002.

38. Chijiwa T, Abe Y, Ikoma N, Yamazaki H, Tsukamoto $\mathrm{H}$, Suemizu H, Kawai K, Wakui M, Nishime C, Matsumoto H, Matsuyama M, Mukai M, Ueyama Y and Nakamura M: Thrombospondin 2 inhibits metastasis of human malignant melanoma through microenvironment-modification in NOD/ SCID/gamma(c)(null) (NOG) mice. Int J Oncol 34: 5-13, 2009.

39. Kazuno M, Tokunaga T, Oshika Y, Tanaka Y, Tsugane R, Kijima H, Yamazaki H, Ueyama Y and Nakamura M: Thrombospondin-2 (TSP2) expression is inversely correlated with vascularity in glioma. Eur J Cancer 35: 502-506, 1999.

40. Nakamura M, Oida Y, Abe Y, Yamazaki H, Mukai, M, Matsuyama M, Chijiwa T, Matsumoto H and Ueyama Y: Thrombospondin-2 inhibits tumor cell invasion through the modulation of MMP-9 and uPA in pancreatic cancer cells. Mol Med Rep 1: 423-427, 2008. 
41. Fontanini G, Boldrini L, Chine S, Pisaturo F, Basolo F, Calcinai A, Lucchi M, Mussi A, Angeletti CA and Bevilacqua G: Expression of vascular endothelial growth factor mRNA in non-small-cell lung carcinomas. Br J Cancer 79: 363-369, 1999.

42. Decaussin M, Sartelet H, Robert C, Moro D, Claraz C, Brambilla $\mathrm{C}$ and Brambilla E: Expression of vascular endothelial growth factor (VEGF) and its two receptors (VEGFR1-Flt1 and VEGF-R2-Flk1/KDR) in non-small cell lung carcinomas (NSCLCs): correlation with angiogenesis and survival. J Pathol 188: 369-377, 1999.

43. O'Byrne KJ, Koukourakis MI, Giatromanolaki A, Cox G, Turley H, Steward WP, Gatter K and Harris AL: Vascular endothelial growth factor, platelet-derived endothelial cell growth factor and angiogenesis in non-small-cell lung cancer. $\mathrm{Br} \mathrm{J}$ Cancer 82: 1427-1432, 2000.

44. Baillie R, Carlile J, Pendleton N and Schor AM: Prognostic value of vascularity and vascular endothelial growth factor expression in non-small cell lung cancer. J Clin Pathol 54: 116-120, 2001
45. Han H, Silverman JF, Santucci TS, Macherey RS, d'Amato TA, Tung MY, Weyant RJ and Landreneau RJ: Vascular endothelial growth factor expression in stage I non-small cell lung cancer correlates with neoangiogenesis and a poor prognosis. Ann Surg Oncol 8: 72-79, 2001.

46. Stefanou D, Batistatou A, Arkoumani E, Ntzani E and Agnantis NJ: Expression of vascular endothelial growth factor (VEGF) and association with microvessel density in smallcell and non-small-cell lung carcinomas. Histol Histopathol 19: 37-42, 2004

47. Tomii Y, Yamazaki H, Sawa N, Ohnishi Y, Kamochi J, Tokunaga T, Osamura Y, Sadahiro S, Kijima H, Abe Y, Ueyama Y, Tamaoki $\mathrm{N}$ and Nakamura M: Unique properties of 189 amino acid isoform of vascular endothelial growth factor in tumorigenesis. Int J Oncol 21: 1251-1257, 2002.

48. Inoue K, Ozeki Y, Suganuma T, Sugiura Y and Tanaka S: Vascular endothelial growth factor expression in primary esophageal squamous cell carcinoma. Association with angiogenesis and tumor progression. Cancer 79: 206-213, 1997. 